\title{
The Ecological Niches of Poisonous Plants in Range Communities
}

\author{
E. H. CRONIN, PHIL OGDEN, JAMES A. YOUNG, AND WILLIAM LAYCOCK
}

Highlight: So many diverse plant species are poisonous to domestic livestock that it seems highly improbable that a universal competitive advantage is common to all poisonous species. Plant poisons may have originated in mutations that were of no direct adaptive value. Once these secondary chemical products became established in the physiologic systems of plants, their interactions with insects and rodents that consumed the seeds, seedlings, or herbage of the plant may have given them adaptive value. Evolution of resistance to poisons of plants by the herbivores probably has led to the proliferation of species in genera that contain many poisonous species such as $A$ stragalus. The study of such relationships should be given priority in range ecology to achieve effective management of the range resource. Some poisonous plant species have also evolved allelopathic defense mechanisms that enhance competitive advantages. The coevolution of poisonous plants, large herbivores, and rumen microfloras offers intriguing possibilities for study that may answer questions basic to the future success of range management.

Because of the tremendous economic losses that the livestock industry incurs from plant-induced poisoning, it becomes imperative that range managers study the ecology of poisonous plants in rangeland communities. This topic is difficult to cover adequately in a short presentation because of the number of poisonous plants and the variations among them. We have relatively few precise data or facts, which are the finished products of research. Instead we must deal with

Authors are plant physiologist, U.S. Department of Agriculture, Science and Education Administration, Federal Research, Poisonous Plant Research Laboratory, Logan. Utah 84321; Dep. of Range Management. University of Arizona, Tucson 84719; professor of range management. School of Renewable Resources, University of Arizona. Tucson 84719; range scientist, U.S. Dep. Agr., SEA-FR, Renewable Resource Center. University of Nevada, Reno 89512; and range scientist, U.S. Dep.

Agr., SEA-FR, Crops Research Laboratory, Fort Collins, Colo. 80521.

Manuscript received March 30, 1978. ideas, which are the essential raw materials of research. We will discuss the diverse habitats occupied by poisonous species and speculate on the role of secondary chemical compounds in the ecology of plants.

\section{Spectrum of Poisonous Plants}

Many authors (e.g., Sampson and Malmsten 1935; Muenscher 1958) have attempted to formulate a definition of a poisonous plant. The following elements are basic to all definitions: (a) a poisonous plant contains some specific substance, which (b) when consumed by herbivores under specific circumstances, (c) causes injury to susceptible animals. Purely mechanically injurious plants are usually exempted from such definitions because they lack the specific injurious chemical agent.

The "specific circumstances" under which the poisonous plants must be consumed pertains to the modifying role of variable environmental conditions in determining what plants are poisonous. For example, a plant may provide excellent forage while it is rapidly growing, but become toxic after a frost.

Species, breeds, and individual grazing animals differ in susceptibility to plant poisoning. Losses of sheep from halogeton (Halogeton glomeratus) are sometimes very great, but cattle often use halogeton-infested ranges without apparent ill effects even though cattle can be poisoned from consuming halogeton. Conversely, larkspur (Delphinium spp.) is not considered to be a major threat to sheep, but it is a major threat to cattle (Stoddart et al. 1975). The physical condition of the consuming animal also influences its sus- 
ceptibility. Animals may be susceptible to plant poisons that produce birth defects (teratogenic effects) only at specific stage of pregnancy (Binns et al. 1965). Animals may be susceptible to a plant poison only if they are preconditioned by a specific diet. For example, for sheep to be photosensitized by eating horsebrush (Tetradymia spp.) they must have previously eaten black sagebrush (Artemisia nova) (Johnson 1978). In general, animals in poor condition are less susceptible to nitrate poisoning than animals in good condition.

The type of injury produced by the plant poison may be highly variable. We usually associate poisonous plants with acute symptoms and death losses, but chronic ill health or pregnancy-associated symptoms also may be a result of plant poisoning.

In ruminants, which are our major consumers on rangelands, rumen microflora break down high-cellulose-content forage and synthesize nutrients. Some types of plant poisons, such as essential oils, may indirectly harm ruminants by interfering with the function of the rumen microflora (Nagy et al. 1964). The rumen microflora of sheep can break down oxalates if they have foraged on plants containing small quantities of oxalates for a short period (2-3 days). Then they can ingest as much as $75 \%$ more halogeton without ill effects (James and Cronin 1974).

\section{Community Ecology of Poisonous Plants}

The great variation in poisonous plants find them represented in a host of plant communities. In the traditional view of the ecology of poisonous plants, the occurrence of poisonous plants is equated with poor range condition. For example, Heady (1975) states in a recently published textbook on range management, "If rangeland is properly maintained in excellent condition, losses from poisonous plants can be effectively reduced." This assumption is probably influenced by three factors: (a) some poisonous plants are colonizers that increase in density with overgrazing; (b) many plant poisons are dosage dependent and as desirable forage plants decrease in density with declining range condition, grazing animals consume proportionately larger amounts of the toxic plants; and (c) animals in poor physical condition from grazing degraded rangelands are often most susceptible to plant poisoning (except for nitrate poisoning as previously noted).

\section{Pristine Communities}

The water hemlocks (Cicuta spp.) are among the acutely poisonous species that occupied specific habitats under pristine conditions and that still are restricted to specific habitats (Brewer et al. 1876; Greene 1889; March et al. 1914; Fleming et al. 1920). Water hemlock may be the source of reports by early trappers and explorers of poison waters in the West (Vestal 1974). The plant is certainly responsible for the naming of two streams - the "Malad River" (from the French word "maladie" meaning sickness); one is on the Utah-Idaho border and empties into the Great Salt Lake, and the other is a tributary of the Snake River near Twin Falls, Idaho (Howell 1960). The specific marshy habitats favored by water hemlock probably have decreased with the drainage of wet meadows to favor forage production.

Although they are adapted to more variable and contrasting environments than water hemlock, the larkspurs ( $\mathrm{Del}$ - phinium spp.) also occur in pristine plant communities in equilibrium with their environments (Sampson 1944; Fleming et al. 1933; Kurameto and Bliss 1970; Franklin and Dyrness 1973; Sawyer and Thornburgh 1977). The larkspurs have persisted after the introduction of domestic livestock to western rangelands. The tall larkspurs grow in the mountains on sites with deep soils. They tend to remain green throughout the growing season. Tall larkspurs require an almost continuous supply of soil moisture throughout the growing season. They are climax species as an understory under trees or in open meadows. They can be the most tenacious species of the pristine vegetation, persisting after the associated species are destroyed. But some species of tall larkspur, such as $D$. barbeyi, may also increase in density when grazing pressure is reduced (Ellison 1954).

\section{Seral Dominants}

Horsebrush (Tetradymia canescens) may occur as an occasional species in Artemisia communities in high condition, but often forms pure stands after disturbance of a community (Young and Evans 1974). A prolific root sprouter, horsebrush assumes dominance when the nonsprouting big sagebrush (Artemisia tridentata) is burned in wildfires. After a period of 15 to 20 years without repeated burning, big sagebrush reestablishes and horsebrush decreases in dominance.

If the frequency of disturbance is increased as with promiscuous burning, the tenure of horsebrush dominance is prolonged. As a component of the natural environment, the poisonous horsebrush will not completely disappear with succession, which we usually equate with higher range condition, but it will greatly decrease in abundance.

\section{Decreaser With Burning}

Burroweed (Haplopappus tenuisectus) is a half-shrub that commonly grows on sandy loam and sandy clay-loam soils of the upper southern desert-shrub and lower desertgrassland regions of southwestern Texas, New Mexico, Arizona, and Mexico. Schmutz et al. (1968) listed burroweed as one of the 30 major livestock poisoning plants of Arizona. The poisonous principle is a higher alcohol, tremetol, which also is the poisonous principle of white snakeroot (Eupatorium rugosum), a species that grows in most habitats of the eastern U. S. and Canada (Kingsbury 1964). Both of these species are members of the Compositae plant family, and livestock poisoning from their consumption is most prevalent when more palatable forage is in short supply (Kingsbury 1964; Schmutz et al. 1968). Jimmyweed (Haplopappus heterophyllus) is closely related to burroweed and also contains tremetol. Livestock raised in a burroweed area seem to develop an aversion to it, so locally raised livestock are seldom poisoned by burroweed ingestion unless they are stressed for forage. Severe losses have occurred when livestock not raised in burroweed areas were grazed on ranges with abundant burroweed, especially when grass forage was dry, in May or June.

Burroweed germinates and grows in the cool winter and spring months, and mortality is high during dry winters. The density of burroweed stands, therefore, fluctuates greatly from year to year (Martin 1966). Mortality of burroweed is 
also high in spring or summer fires (Martin 1966). Burroweed seeds germinate immediately following maturity (Meyer 1973) when cool-season moisture is available and, therefore, may become established on sites where warmseason grasses have difficulty in becoming established. Burroweed plants may, therefore, provide protection and favorable microsites for the establishment of desert-grassland grass species on harsh desert shrub sites in favorable years. Cable (1969) and W. Meyer, (unpublished data Univ. of Arizona Student Report) showed that the competition for moisture between warm-season perennial grasses and burroweed is not great.

The ecological niche that burroweed occupies seems to be mostly related to its adaptations for germination and growth in the cool season. The low palatability of burroweed, whether this is a result of the poisonous principle or some other factor, and the reduced frequency of fire on desert grasslands have increased the abundance of this species in the past century. Note that horsebrush increases through rootsprouting after promiscuous burning, whereas burroweed, which depends on seedlings for establishments, increases when fires are suppressed.

\section{Grazing Increaser}

Orange sneezeweed (Helenium hoopesii) is another example of poisonous species that occurs naturally and is of minor importance in pristine plant communities, but increases with misuse or overgrazing. Orange sneezeweed occurs in a variety of vegetation types on high elevation rangelands in most of the western states. Where the range is properly managed, orange sneezeweed is not a common species (Ellison 1954) and often occurs in small, scattered patches. On overgrazed ranges, sneezeweed may be locally abundant or may even be the dominant species on extensive areas (U.S. Forest Service 1937).

\section{Alien Species}

Considering the host of alien annuals that have been introduced to western rangelands (Young et al. 1972), it is remarkable that so few species are poisonous. One major exception is halogeton. This annual weed was introduced to the intermountain area of western North America sometime before 1934. Cronin (1965) described halogeton as "a pioneer invader on disturbed sites in the salt-desert shrub vegetation." Abundant halogeton usually indicates degraded rangelands, but even if such communities could be restored to their pristine balance, limited amounts of halogeton could probably persist on unused environmental potential.

\section{The Ecological Advantage of Being Poisonous}

Poisonous plants obviously have a variety of successional roles and ecological advantages that defy generalization. The basic question considered in this review is, "Does being poisonous always convey any competitive advantage in this wide spectrum of habitats?"

No matter how carefully we state our purpose, we must approach the question obliquely because, in the words of Stebbins (1974): "The evolutionist cannot trace directly the alterations of genes and gene-controlled processes that have been responsible for evolutionary trends. He can observe only the outcome of these changes in terms of alterations in the morphology and the reactions of the adult organisms." In this case the alterations are in the physiologic systems of plants, making them poisonous.

Recently, our understanding of the evolutionary significance of secondary chemical substances in plants has been advanced through research stimulated by the realization that these substances can serve as markers for taxonomic relationships. The use of chromatographic characteristics to establish phylogenetic relationships for the Tridentatae section of Artemisia (Hanks et al. 1973) is an excellent example of such research. This heightened interest has also been expressed in speculation about their value to the plant. Why should most conifers of the temperate zone be richly endowed with terpenes (Levin 1971), and why should alkaloids be widespread in Ranunculaceae (McKay 1974), tannins in Fagaceae (Feeny 1970), essential oils in Labiatae (Stebbins 1974)?

One answer may be that these substances are inevitable products of cellular metabolism which are difficult to excrete and must, therefore, somehow be disposed of by some other route. Stebbins (1974) finds this explanation unsatisfactory for two reasons. First, it does not explain why certain groups of plants have evolved conducting systems, whose elaborate development must be controlled by a large number of genes (Mahlberg 1959), for secondary chemical substances. For example, the families Euphorbiaceae, Apocynaceae, and Asclepiadaceae have evolved not only latex substances, but the specialized and intricate conducting system that ensures the presence of abundant latex in all parts of the plant. Second, secondary chemicals in plants are probably not inevitable products of cellular metabolism. The process of artificial selection used in developing many cultivated derivatives of wild species, such as garden lettuce (Lactuca sativa), has greatly reduced their content of these secondary substances (e.g., those producing bitter taste), but has not reduced the metabolic efficiency or vigor of cultivated lettuce. If the secondary chemicals were necessary byproducts of essential metabolic processes, their removal would surely have disrupted the growth and reproduction of the selections.

In a recent review of chemical interactions between species, Whittaker and Feeny (1971) popularized an explanation of the function of secondary chemicals that was first proposed by Stahl (1888). Stahl suspected that the ability to form secondary substances that are bitter, toxic, or both, (phenylpropanes, acetogenins including flavones and anthocyanidins, terpenoids, and alkaloids) evolved in plants in response to natural selection for the capacity for defense against herbivores. This conclusion is now supported by a large body of evidence (Whittaker and Feeny 1971).

Assuming that the production of a toxic substance by plants is always a defense against grazing predation may be erroneous. For example, the production of oxalates by halogeton may be part of a mechanism to reduce moisture stress. The succulence of halogeton is proportional to the concentration of sodium or potassium chloride in the growth medium, but the major role in promoting succulence is attributed to the chloride ions. The chloride ion was thought to be the element responsible for increased succulence (Williams 1960). If so, then the absorption of potassium or sodium chloride must result in an excess of potassium or sodium cations. Production of oxalic acid 
provides a means of tieing up the excess cations to produce an acceptable sodium balance in halogeton (Waisel 1972). This explanation appears logical in view of the increasing concentration of oxalates in halogeton (Williams 1960) as the soil moisture is depleted over the growing season (Cronin 1965).

The evolution of secondary substances as defense mechanisms appears to be an excellent example of the interaction of natural selection, chance, and adaptive modification along the lines of least resistance. The particular pathway taken by an evolutionary line depends to a certain extent upon chance combinations of genes that exist in the initial population of the line as a result of mutation. For poisonous plants the chance mutation controls the production of a toxic chemical or the loss of the enzyme required to metabolize the toxic chemical. Stebbins (1950) argued that an equally or perhaps more important factor in determining the pathway of adaptation is the innate, genetically controlled pattern of development that exists in a population at any stage in its evolution. This pattern is important because the direction of adaptation will often be determined according to the principle of adaptive modification along the lines of least resistance, i.e., modification involving the least possible alteration of existing biosynthetic pathways.

We can illustrate this principle with the genus Astragalus. Barneby (1964) listed 368 species of North American Astragalus. Williams and Barneby (1977) determined that 204 of these species contain nitrocompounds that are potentially poisonous to grazing animals. Some ancestral species of Astragalus may have evolved by chance mutation the initial nitrocompound. As the genus has proliferated in a variety of habitats the process of speciation has probably been accompanied by modification of the original nitrocompound. Green and Palmblad (1975) found that chemicals in the seed pods were partly responsible for differential predation on seeds of $A$. cibarius and $A$. utahensis. They concluded that selection pressure by seedeating insects may account for much of the chemical diversity exhibited by the genus Astragalus. These nitrocompounds may provide an adaptive advantage in protecting Astragalus plants from attacks by insects, rodents, or both during some portion of the plants' life cycle. Diversification may well have been largely a matter of evolving new substances for defense against predators that had evolved immunity to the preexisting ones.

Thus, the operation of adaptive modification along the lines of least resistance during the speciation of Astragalus is demonstrated by the spread of nitrocompounds or their antilogies. It does not result in the evolution of new alkaloids or other families of toxic compounds; i.e., preexisting bisynthetic pathways were altered as little as possible. Small changes lessen the chance of disrupting the physiology of the plant.

\section{Allelopathic Plants}

In addition to compounds that act as direct defenses against destructive herbivores, many adult plants produce allelopathic substances that prevent the growth of competing species in the immediate vicinity (Rice 1974). Allelopathic plants are of interest in this discussion because of the evolutionary parallel in selection for allelopathic and poisonous substances in plants. In many areas of former salt desert vegetation in eastern Nevada and western Utah, the plant cover consists almost entirely of the alien species halogeton. Small quantities of halogeton are utilized by livestock and wild herbivores throughout the growing season, regardless of the amount of available forage, but lethal levels are consumed only when other feed is limited or absent. The poisonous principle in halogeton is soluble oxalates (James 1972). Most losses occur when hungry animals are introduced to vegetation with abundant halogeton and after they are watered following a prolonged period of acute thirst (James and Cronin.1974).

Eckert and Kinsinger (1960) determined that the leachate from halogeton increased the soil $\mathrm{pH}$, electrical conductivity, exchangeable sodium and potassium, soluble sodium, potassium, calcium, and magnesium, modulus of rupture; and decreased percolation and capillary rise of water. The density of halogeton increases as the salinity of the soil increases (Williams 1960). Once halogeton is established and has modified the soil, the site is closed to the establishment of other plant species, affording a tremendous advantage to halogeton (Kinsinger and Eckert 1961).

A similar type of allelopathic effect through the concentration of soluble salts occurs with the poisonous native shrub greasewood (Fireman and Hayward 1952). However, the widely spaced greasewood plants are less effective than dense herbaceous stands of halogeton in eliminating competition from other species. The widely distributed bracken fern (Pteridium aquilinum) contains a cyanogenic glycoside (Cooper-Driver and Swain 1976) that is poisonous to livestock (Muenscher 1958). Water extracts from bracken fern significantly reduced growth, germination, or both in competing herbaceous vegetation (Gliessman and Muller 1972). The phytotoxic principle was suspected to be a phenolic compound.

\section{Natural Selection and Poisonous Plants}

If we assume that being poisonous reduces the amount of photosynthetic tissue removed by herbivores and, therefore, improves the survival characteristics of the plant, then the selective advantage is obvious. However, with large herbivores such as cattle, horses, and sheep on western rangelands of the United States this assumption is probably false for two reasons. First, being poisonous cannot reduce consumption of a plant's photosynthetic tissue by livestock unless the plant is so acutely toxic that the animals drop dead at the first taste or unless the animals sense the toxicity of the plant and do not graze the herbage. We know from the tremendous economic losses from plant poisoning that both situations are not always met. An example of an effect opposite to that in our assumption is found in the Astragalus species that cause locoism: once animals graze on locoweeds they tend to seek and graze them to the exclusion of other forage. Second, plants in the United States west of the Rocky Mountains have been grazed by large herbivores for so short a time that grazing pressure may not have contributed to selection of plants in this region. Most of the large herbivores native to North America were lost by Pleistocene extinction (Martin 1967); west of the Rocky Mountains the depletion of large herbivores was especially significant. The major native plant species that cause poisoning of domestic livestock on far western rangelands probably evolved for a considerable period of time relatively free of grazing by concentrations of large herbivores. 
Rangeland ecosystems that existed during the Pleistocene or at least during an interglacial period may contain species that evolved under intense grazing pressure from large herbivores. However, in view of the general desiccation of western North America following the Pleistocene and the youthfulness of semiarid and arid ecosystems (Axelrod 1950 ), it is doubtful that many poisonous rangeland species of western North America originated in early Pleistocene times.

As range managers, we often forget that there are major consumers of herbage besides large domesticated herbivores. Insects and rodents may consume as much or more forage than cattle or sheep. Insects can be especially effective predators on seeds or seedlings. Indirect evidence of the interrelationship of herbivorous insects and poisonous plants is provided by comparing the prevalence of St. Johnswort (Hypericum perforatum) (a) after it was introduced to new environments without its natural insect predators and (b) after some of its natural consumers were introduced for biological control. St. Johnswort is a common roadside plant in Europe. It was accidentally introduced to the western United States and to Victoria, Austalia, where it became a severe pest on rangelands, partially because of its poisonous characteristics. The later introduction of several species of insects that naturally feed on St. Johnswort contributed to successful biological control (Huffaker and Holloway 1949). The introduction of alien plant species into biological near-vacuums may allow the perpetuation of many new genotypes because of the greatly reduced competition (McKell et al. 1962). Insects have been noted that limit the abundance or dominance of many native species of poisonous plants. For example, the larvae of the beetle Crossidius were found on $55 \%$ of the burroweed plants examined (Parker and Martin 1943). Plant poisons that are poisonous to large herbivores may influence the plants' resistance to insect attacks.

Plants produce compounds that repel insects (repellents), inhibit or prevent insect feedings (antifeedants), inhibit insect growth or development (juvenile and molting hormones), and kill insects outright (toxicants) (Jacobson 1975). Among the plants that are toxic to both livestock and insects are larkspurs that contain the chemical delphinine; Solanum spp. that contain glycoalkaloids; and species of Umbelliferae that contain myristicin (Jacobson 1975). Researchers throughout the world have found curare-like compounds, dyes, and insecticides that controlled locusts, grasshoppers, maggots, and ticks in various species of larkspur (Crawford 1907).

Evidence that plants produce specific compounds that have deleterious effects on rodents is limited. However, there is ample evidence of preference of avoidance of certain plant species by specific rodents. Concentrated research including chemical analysis to isolate substances that influence rodent preference, probably would reveal relationships like those noted between poisonous plants and insects.

Certain poisonous plants seem to have a symbiotic relationship with rodents. Orange sneezeweed increased in areas of pocket gopher disturbance in meadows (Turner 1973), and the roots of orange sneezeweed are the most abundant herbage found in the caches of pocket gophers (Ward 1973). The rodents apparently utilize the plant without toxic effects.

From an evolutionary standpoint, seed and seedling characteristics that have adaptive value are particularly significant (Stebbins 1974). The seeds of poisonous plants are not necessarily poisonous. The seed of some poisonous species of lupine (Lupinus) are acutely toxic to sheep (Marsh and Clawson 1916), but quail (Coturnix spp.) relish the seeds of water hemlock (Cicuta douglasii) with no apparent toxic effects (personal communication, Dr. Donald Klebenow, University of Nevada, Reno). Lupine seeds are often difficult to collect from native stands because the seed pods are infested with insect larvae. We know of no published data on the relative amount of seed predation by insects or foliage consumption in poisonous versus nonpoisonous species of lupine. However, field observations have shown insect predation to be important in the seed ecology of Lupinus sericeus and Astragalus lentiginosus (unpublished data, SEA-FR, Poisonous Plant Research Laboratory, Logan, Utah).

In burroweed, a poisonous plant that depends on seedling establishment for regeneration, seed-germination and seedling-growth characteristics are obviously important in controlling population size (Meyer 1973).

The central point is that in the western United States the ecologic advantage of being poisonous may be found in plant-insect, plant-rodent, or plant-plant (allelopathic) relationships rather than in relationships between plants and large herbivores, especially large herbivores that have not evolved with the plants. As previously stated, the substance of this paper is ideas-ideas as raw material for research. The integrated investigation of plant, insect and rodent ecology is a prerequisite for understanding the ecologic niches of poisonous plants.

\section{Coevolution of Poisonous Plants and Large Herbivores}

Halogeton is an example of a poisonous plant that has evolved in central Asia under grazing pressure from wild and domestic animals. Halogeton has many characteristics that apparently give it a competitive advantage. Its potential for growth in saline soils and its enrichment of surface soils with salts leached from its herbage have already been mentioned. Another survival characteristic of halogeton is its production of polymorphic seed with differential dormancy and germination characteristics (Robocker et al. 1969). In its evolution concurrent with the domestication of livestock, halogeton was apparently preconditioned for growth and reproduction in an excessively grazed salt-desert environment (Young et al. 1972). Although numerous individual characteristics that impart an apparent competitive advantage can be identified in alien annuals such as halogeton, the most important characteristic that preconditions persistence and persistent dominance is a breeding system that allows rapid genotypic adjustments in a changing environment (Young and Evans 1976).

As previously mentioned, Pleistocene extinction so depleted large herbivores in western North America that the evolution of large herbivores and native poisonous plants seems improbable. An exception is the pronghorn (Antilocapra americana), which apparently is a true native to North America and not an immigrant from Asia during the Pleistocene (Martin and Guiday 1967). The pronghorn is probably the only large herbivore in western North America that is dependent on the seedheads and herbage of big sagebrush (Artemisia tridentata subsp. tridentata) during a portion of the year. Mule deer (Odocoileus hemionus) may 
utilize relatively large amounts of big sagebrush in late winter, but the activity of the rumen microflora and ultimately of the mule deer is depressed by the essential oils of the sagebrush (Nagy et al. 1964). It also seems likely that subspecies of $A$. tridentata other than subsp. tridentata are usually consumed in abundance by mule deer (Hanks et al. 1973).

As a forage base for herbivores, big sagebrush has the obvious advantages of abundance and relatively high nutritional value (Nagy et al. 1964). The fact that relatively few species of Artemisia of the section Tridentatae are preferred by domestic livestock is of fundamental significance in the reaction of sagebrush/grassland to the introduction of grazing by domestic livestock (Stewart 1936).

The essential oil content of sagebrush species is apparently the reason that sagebrush is not preferred by ruminants except pronghorns. Of what adaptive advantage to the Artemisia species are these essential oils? The density of mule deer and elk (Cervus canadensis) in the pristine environments of the sagebrush/grassland was probably never sufficient to pressure for the selection of what must be a complexly inherited characteristic (Young et al 1976).

The section Seriphidium of Artemisia is Eurasian in distribution. This section apparently evolved from primitive stock in arid areas of Kazakhstan, U.S.S.R., and adjacent central Asia (Filatova 1974). The evolution of this section probably paralleled the evolution of the section Tridentatae in North America (McArthur and Plummer 1978). Chemotaxonomic studies have shown distinct differences between the sections. The sesquiterpene-lactone-anthelmintic santonin, is common to all members of the section Seriphidium, but has not been found in section Tridentatae (Polyakov 1961). We do not know the significance of this compound in grazing preference by large herbivores, but santonin does illustrate that a specific secondary compound may become a fixed characteristic in one of two sections that have evolved in separate but similar ecosystems. We believe that many members of the section Seriphidium have been subjected to intense grazing pressure by a broad spectrum of domesticated herbivores since the close of the Pleistocene (Young et al. 1972). At the same time, the section Tridentatae has diversified, with most members containing secondary chemical compounds that limit their preference by grazing animals.

In the section Tridentatae are the related species $A$. arbuscula, which is relatively preferred by livestock and big game species, and $A$. nova, which is highly preferred by sheep (Hanks et al. 1973). Despite their lack of the essential oils found in other species of Artemisia, these two species are able to survive and reproduce in specific environments just as domestic lettuce survives in cultivated environments despite selection for less bitter cultivars. Apparently essential oils are not necessary for the growth of Artemisia species. Nonetheless, essential oils might be of adaptive value in repelling insects or rodents. Let us consider those times at the close of the Pleistocene when North American rangelands were rich with large herbivores (Mehringer 1977). Species of Mammuthus, Camelops, Bison and Nothrotherium flourished and required a hugh forage base. The alternating periods of moisture and desiccation during the Pleistocene favored repeated evolutionary cycles and diversification (Axelrod 1950). The desiccation that followed the last ice age was also a powerful evolutionary stimulus
(Stebbins 1974, Axelrod 1972). How much of an adaptive advantage were essential oils to the ancestral stock of the Artemisia spp. in the section Tridentatae, and did they and other plant poisons play a role in Pleistocene extinctions? Relatively simple successional changes on rangelands, such as the replacement of downy brome (Bromus tectorum) by medusahead have not been explained by any single factor even with intensive research during roughly the time of the change. A monumental change, such as the loss of all the large herbivores off western ranges at the close of the Pleistocene, undoubtedly has many interacting causes. The evolution by forage species of secondary chemical substances that are toxic or that limit grazing preference is a possible cause that should be considered, especially for species that characterize landscapes such as Artemisia, Sarcobatus, Larrea and Quercus, or species that dominate seral communities such as Chrysothamnus and Tetradymia. Remember that rumen microfloras of extant animal species have proven extremely responsive to environmental changes. Among the most perplexing questions to challenge the student of the quaternary sciences are the causes of the Pleistocene extinctions and the increase of unpreferred shrubs on western rangelands, and the possibility that these two phenomena share common roots. Studies of the ecological niches of poisonous plants in range communities may provide basic understanding useful in solving these questions.

\section{Literature Cited}

Axelrod, D. I. 1950. The evolution of desert vegetation in western North America. Carnegie Inst. Washington Publ. 590:215-306.

Axelrod, D. I. 1972. Edaphic aridity as a factor in angiosperm evolution. Amer. Natur. 1106:311-320.

Barneby, R. C. 1964. Atlas of North America Astragalus. Mem. New York Gard. 13:1-183.

Binns, W., J. L. Shupe, R. F. Keeler, and L. F. James. 1965. Chronologic evaluation of teratogenicity in sheep fed Veratrum californicum. J. Amer. Vet. Med. Ass. 147:839-842.

Brewer, W. H., S. Watson, and A. Gray. 1876. California Geological Survey. Botany of California. Welch Bigelon and Col., Univ. Press, Cambridge, Mass. 628 p.

Cable, D. R. 1969. Competition in the semi-desert grass-shrub type as influenced by root systems, growth habits, and soil moisture extraction. Ecology. 50:27-38.

Cooper-Driver, G. A., and T. Swain. 1976. Cyanogenic polymorphism in bracken in relation to herbivore predation. Nature 260:604.

Crawford, A. C. 1907. The larkspurs as poisonous plants. U.S. Dep. Agr. Plant Ind. Bull. III. 87 p.

Cronin, E. H. 1965. Ecological and physiological factors influencing chemical control of Halogeton glomeratus. U.S. Dep. Agr. Tech. Bull. 1325. $65 \mathrm{p}$.

Eckert, R. E., Jr., and F. E. Kinsinger. 1960. Effects of Halogeton glomeratus leachate on chemical and physical characteristics of soils. Ecology 41:785-790.

Ellison, L. 1954. Subalpine vegetation of the Wasatch Plateau, Utah. Ecol. Monogr. 24:89-183.

Feeny, P. 1970. Seasonal changes in oak leaf tannins and nutrients as a cause of spring feeding by winter moth caterpillars. Ecology 51:565-581.

Filatova, N. S. 1974. Kariosistematika dvukh vidov polynei podroda Seriphidium (Bess.) Rouy. [Karyotaxonomy of two species of worm wood of the subgenus Seriphidium (Bess.) Rouy.] lzv. Akad. Kaz. U.S.S.R. Ser. Biol. 1, p. 16-20.

Fireman, M., and H. E. Hayward, 1952. Indicator significance of some shrubs in the Escalante Desert. Utah Bot. Gaz. 114:143-155.

Fleming, C. E., M. R. Miller, and L. R. Vawter. 1923. The low larkspur (Delphinium andersoni) a plant of the spring range, poisonous to cattle. Nevada Agr. Exp. Sta. Bull. 105. 22 p.

Fleming, C. E., N. F. Peterson, W. R. Wright, and R. C. Louck. 1920. The poison parsnip or water hemlock (Cicuta occidentalis) a plant deadly to livestock in Nevada. Nevada Agr. Exp. Sta. Bull. 100. 23 p. 
Franklin, J. F., and C. T. Dyrness. 1973. Natural vegetation of Oregon and Washington. U.S. Dep. Agr. Forest Serv. Gen. Tech. Rep. PNW-8. $417 \mathrm{p}$.

Gliessman, S. R., and C. H. Muller. 1972. The phytotoxic potential of bracken, Pteridium aquilinum (L.) Kuhn. Madrono 21:299-304.

Greene, E. L. 1889. Vegetative characters of the species of Cicuta. Brittonia 2:1-11.

Green, T. W., and I. G. Palmblad. 1975. Effects of insect seed predators on Astragalus cibarios and Astragalus utahensis (Leguminosae). Ecology $56: 1435-1440$.

Hanks, D. L., E. D. McArthur, R. Stevens, and A. P. Plummer. 1973. Chromatographic characteristics and phylogenetic relationships of Artemisia, section tridentatae. U.S. Forest Serv. Res. Pap. INT 141. $24 \mathrm{p}$.

Heady, H. F. 1975. Rangeland Management. McGraw-Hill Book Co., New York. 460 p.

Howell, G. F. 1960. Early history of Malad Vallcy. MA Thesis. Dep. of History, Brigham Young Univ. 127 p.

Huffaker, C. B., and J. K. Holloway. 1949. Changes in range plant population structure associated with feeding of imported enemies of Klamath weed (Hvpericum perforatum L.). Ecology 30:167-175.

Jacobson, M. 1975. Insecticides from plants-a review of the literature 1954-1971. Agr. Res. Serv. Agr. Handbook. 461. U.S. Gov. Printing Office. Washington, D.C. 210 p.

James, L. F. 1972. Oxalate toxicosis. Clin. Toxicol. 5:231-243.

James, L. F., and E. H. Cronin. 1974. Management practices to minimize death losses of sheep grazing halogeton infested range. J. Range Manage. 27:424-426.

Johnson, A. E. 1978. Tetradımia toxicity-a new look at an old problem. p. 209-216. In: R. F. Keeler, K. R. Van Kampen and L. F. James (Ed.) Effects of Poisonous Plants on Livestock. Academic Press, New York.

Kingsbury, John M. 1964. Poisonous Plants of the United States and Canada. Prentice-Hall, Inc., Englewood Cliffs, New Jersey. 626 p.

Kinsinger, F. E., and R. E. Eckert, Jr. 1961. Emergence and growth of annual and perennial grasses and forbs in soils altered by halogeton leachate. J. Range Manage. 14: 194-197.

Kuramoto, R. T., and L. C. Bliss. 1970. Ecology of subalpine meadows in the Olympic Mountains, Washington. Ecol. Monogr. 40:317-341.

Levin, D. A. 1971. Plant phenolics: an ecological perspective. Amer. Natr. 105:157-181

Mahlberg, P. G. 1959. Development of the non-articulated laticifer in proliferated embryos of Euphorhia marginata Pursh. Phytomorphology 9:156-162.

Marsh, C. D., and A. B. Clawson. 1916. Lupines as poisonous plants. U.S. Dep. Agr. Bull. 405.4 p.

Marsh, C. D., A. B. Clawson, and H. Marsh. 1914. Cicuta or water hemlock. U.S. Dep. Agr. Bull. 69. 27 p.

Martin, P. S. 1967. Pre-historic overkill, p. 75-120. In: P. S. Martin and H. E. Wright, Jr. (Ed.). Pleistocene Extinctions, the Search for a Causc. Vol. 6. Proc. of VIII Congr. of Internat. Ass. for Quaternary Res. Yale Univ. Press. New Haven, Conn. 543 p.

Martin, P. S., and J. E. Guiday. 1967. Bestiary for Pleistocene biologist. p. 1-62. In: P. S. Martin and H. E. Wright, Jr. (Ed.). Pleistocene Extinctions, the Search for a Cause. Vol. 6. Proc. of the VIII Congr. of Internat. Ass. for Quaternary Res. Yale Univ. Press. New Haven, Conn. 543 p.

Martin, S. C. 1966. The Santa Rita Experimental Range. U.S. Forest Serv. Res. Pap. No. 22. Rocky Mountain Forest and Range Exp. Sta. Ft. Collins, Colo. 24 p.

McArthur, E. D., and A. P. Plummer. 1978. Biogeography and management of native western shrubs: a case study, section Tridentatae of Artemisia. In: K. T. Harper and J. L. Reveal (Ed.). Biogeography Symposium. Great Basin Nat. Mem. No. 2. Brigham Young Univ. Press. Provo, Ut.

McKell, C. M., J. P. Robinson, and J. Major. 1962. Ecotypic variation in Medusahead, an introduced annual grass. Ecology 43:686-698.

McKey, Doyle. 1974. Adaptive patterns in alkaloid physiology. Amer. Natur. 108:305-320.

Mehringer, P. .J., Jr. 1977. Great Basin late quaternary environments and chronology. p. 113-177. In: D. D. Fowler (Ed.). Models and Great Basin Prehistory. Desert Research Institute Pub. in The Social Sci. No. 12. Desert Research Institute. Reno, Nev.
Meyer, W. W. 1973. Effect of $\mathrm{pH}$ on the germination of burroweed ( Haplopappus tenuisectus) at a constant osmotic pressure. MS Thesis, New Mexico State Univ. Las Cruces. 90 p.

Muenscher, W. C. 1958. Poisonous Plants of the United States. The Macmillan Co., New York. 277 p.

Nagy, J. G., H. W. Steinoff, and G. M. Ward. 1964. Effect of essential oils of sagebrush on deer rumen microbial functions. J. Wildlife Manage. 28:784-790.

Parker, K. W., and S. C. Martin, 1943. Beetle helps control burroweed invasion. Arizona Stockman. 9(5):4,16.

Polyakov, P. P. 1961. Artemisia, p. 425-631. In: V. I.. Komarou (Ed.) Flora of the U.S.S.R. Vol. 26. Izdatel 'stuo Akademii Nauk SSR, Leningrad. $938 \mathrm{p}$.

Rice, E. L. 1974. Allelopathy. Academic Press, New York. 353 p.

Robocker, W. C., M. C. Williams, R. A. Evans, and P. J. Torrel. 1969. Effects of age, burial, and region on germination and viability of halogeton seed. Weed Sci. 17:63-65.

Sampson, A. W. 1944. Plant succession on burned chaparral lands in Northern California. Univ. California Agr. Exp. Sta. Bull. 685. Berkeley. $144 \mathrm{p}$.

Sampson, A. W., and H. E. Malmsten. 1935. Stock poisonous plants of California. California Agr. Exp. Sta. Bull. 593. 90 p.

Sawyer, J. O., and D. A. Thornburgh. 1977. Montane and subalpine vegetation of the Klamath Mountain, p. 699-732. In: M. G. Barbour and J. Major (Ed.). Terrestrial Vegetation of California. John Wiley \& Sons, New York.

Schmutz, E. M., B. N. Freeman, and R. E. Reed. 1968. Livest ock-poisoning plants of Arizona. The Univ. of Arizona Press. Tucson. $176 \mathrm{p}$.

Stahl, E. 1888. Pflanzen and Schnecken. Biologische Studie Uber die Schutzmittel der Pflanzen gegen Schneckenfrass. Jevaische Z. Naturw. 22:557-684

Stebbins, G. L., Jr. 1950. Variation and Evolution in Plants. Columbia Univ. Press, New York. 389 p.

Stebbins, G. L., Jr. 1974. Flowering Plants-Evolution Above the Species Level. Belknap Press of Harvard Univ. Cambridge, Mass. 399 p.

Stewart, G. 1936. History of range use. p. 119-133. In: Western Range Senate Document No. 199, 74th Congress; 2 nd Session. U.S. Gov. Printing Office, Washington, D.C.

Stoddart, L. A., A. D. Smith, and T. W. Box. 1975. Range Management. 3rd Ed. McGraw-Hill Book Co.. New York. 532 p.

Turner, G. T. 1973. Effects of pocket gophers on the range. In: Pocket Gophers and Colorado Mountain Rangeland. Colorado State Univ. Exp. Sta. Bull. 554S 90 p.

U.S. Forest Service. 1937. Range Plant Handbook. U.S. Dep. Agr. Unnum. Pub. 512 p.

Vestal, S. 1974. Jim Bridger-Mountain Man. Univ. of Nebraska Press. Lincoln. 312 p.

Waisel, Y. 1972. Biology of Halophytes. Academic Press, New York. 412 p.

Ward, A. L. 1973. Food habits and competition, p. 51-61. In: Pocket Gophers and Colorado Mountain Rangeland. Colorado State Univ. Exp. Sta. Bull. 554S. 90 p.

Whittaker, R. H., and P. P. Feeny. 1971. Allelochemics: chemical interactions between species. Science 171:757-770.

Williams, M. C., and R. C. Barneby. 1977. The occurrence of nitrotoxins in North American Astragalus (Fabaceae). Brittonia 29(3):310-326.

Williams, M. C. 1960. Effect of sodium and potassium salts on growth and oxalate content of halogeton. Plant Physiol. 35:500-505.

Young, J. A., and R. A. Evans. 1974. Population dynamics of green rabbitbrush in disturbed big sagebrush communities. J. Range Manage. 27: 127-132.

Young, J. A., and R. A. Evans. 1976. Response of weed populations to human manipulations of the natural environment. Weed Sci. 23:186-190.

Young, J. A., Evans, R. A., and J. Major. 1972. Alien plants in the Great Basin. J. Range Manage. 25:194-201.

Young, J. A., R. A. Evans, and P. T. Tueller, 1976. Great Basin plant communities-pristine and grazed. p. 187-215. In: Holocene Environmental Change in the Great Basin, Robert Elston (Ed.). Nevada Archiol. Survey Res. Pap. No. 6. Reno. 